\title{
IMPACT OF EXCESSIVE USE OF FACEBOOK ON THE YOUTH OF KARACHI
}

\author{
Yasmeen Sultana* \\ SadafGhaffar ${ }^{* *}$ \\ SamiaSaman ${ }^{* * *}$
}

\begin{abstract}
This research study has done to identify and investigate the major factors behind the excessive usage of Facebook by the youth of Karachi and what kind of impacts they have to face on various aspects of their lives due to this much consumption of Facebook. In this research paper, the researcher has applied both types of methodology, Qualitative as well as Quantitative. The researcher has selected Karachi (The city of Pakistan) as the universe of the study. The data has collected in the manner of survey forms filled by students of different universities and colleges of Karachi; aged from 18 to 30 and the sample size is 50 in which half of the population includes males and half females and 10 interviews are also conducted from teachers and parents of Facebook users. This research study raises major points related to the extreme usage of Facebook which includes the mental and physical conditions of adolescents, children's progress in their academic lives, impacts on relationships and disturbance in routine works. The data has collected in a fair way. The results revealed that Facebook repercussion only happens when an individual is using it in an excessive amount. The researcher suggests that using Facebook could be beneficial only if people learns to use it in manageable levels and if they are able to create a balance between the virtual world and real world.
\end{abstract}

Keywords: Impact; excessive use; Generation X; Generation Y; Generation Z; youth

\section{Introduction}

In the era of innovations and mechanization, as we all know that social media is playing a significant role in making the generation " $y$ and $z$ " faster than any generation could ever existed till today. Social media provides us a variety of options to make the world a global village. If we look at the generation " $x$ " and the previous eras, people were not being able to communicate with each other and even they didn't have any medium to make it happen. But nowadays, the globe rotates on our fingertips, as we have enough mediums and resources to know what's happening around the world. Social media delivers us a number of stages for every determination and goals we want to achieve. Facebook is an online social networking platform with the help of which people can connect with one another from one corner to the other end of the world.

\footnotetext{
"Yasmeen Sultana, Ph.D., Associate Professor, Department of Media Science, Ilma University, Karachi

${ }^{* *}$ Sadaf Ghaffar, Research Scholar, Media and Communication Department, Sindh Madressatul Islam University

${ }^{* * * *}$ Samia Saman, Research Scholar, Media and Communication Department, Sindh Madressatul Islam University
} 
Facebook is a way of communication where you can share things on their own timeline or from other people's account and even from any other page they like, people can comment on other posts and even give reactions on that as well, they can check horoscopes and can play online free games with their friends available online.

Harvard Student "Mark Zuckerberg" launched the facebook.com in February 2004with his college roommates and fellow Harvard University students Eduardo Saverin, Andrew McCollum, Dustin Moskovitz and Chris Hughes. The founders had initially limited the website's membership to the students of the Harvard University, but later on, expanded it to colleges in the Boston area, the Ivy League, and Stanford University.

\section{Operational Definitions}

Impact: In this research study, impact refers to the best and the worst effects of Facebook on youth's life.

Excessive Use: In this research paper, excessive use refers to the use that is elsewhere desires and out of limits. For the usage of Facebook by the youth

Generation X: It refers to the generation which includes our parents and grandparents who had seen a simple lifestyle.

Generation Y:IT Generation y refers to the generation of present time youth. The term targets the ones who are in the phase of experiencing.

Generation Z:IT Generation Z refers to the upcoming generation who are born and growing in an advanced technological world.

\section{Research Questions}

- How does Facebook affect various aspects of children's life?

- What are the factors of Facebook that make an individual antisocial?

- What is the impact of Facebook on the academic progress of youngsters?

- What is the relationship between the mental disorders of adolescents and Facebook?

\section{Research Hypothesis}

- $\quad$ Facebook likely affects various aspects of children's life.

- The factors of Facebook likely affect an individual to make him antisocial.

- $\quad$ The impact of Facebook likely affects youngsters' academic progress.

- $\quad$ Facebook likely affects mental disorders of adolescents. 


\section{Objectives of the Study}

\section{Main Objective}

- $\quad$ To find out the impact of excessive use of Facebook on youth.

\section{Specific Objectives}

- To identify the change, bring by Facebook in the various aspects of children's life.

- To investigate factors of Facebook that makes an individual antisocial.

- To find out the impact of Facebook on the academic progress of youngsters.

- To investigate the relationship between mental disorders of adolescents and Facebook.

\section{Literature Review}

Reynol Junco in 2012 researched on "The relationship between frequency of Facebook use, participation in Facebook activities, and student engagement". According to his findings, this much use of Facebook is highly correlated with student's GPA and the frequency of its usage have contained numerous effects on the students. ${ }^{1}$

Urmee Khan in 2009 researched on the topic, according to his findings $65 \%$ of Facebook users accessed their account several times just to see that as if there's any new Facebook notification basis and the amount of time spent varies from just a few minutes to more than an hour on Facebook and its addiction showed negative impact on the academic performance of those student who has used Facebook. ${ }^{2}$

Sana Rouis, et al. in 2011 investigated on "Impact of Facebook Usage on Students Academic Achievement: Role of Self- regulation and trust". In their research, the result of their research specified that Facebook used by extraverted personalities leads a low performance in academics. ${ }^{3}$

Hassan, Hamza, et al. worked on "Effects of Facebook on the life of Medical University Students". They have conducted their research from January 2012 till November 2013 in Dow University of Health Sciences. They have used cross sectional observations and

\footnotetext{
${ }^{1}$ Reynol Junco, "The relationship between Frequency of Facebook Use, Participation in Facebook Activities, and Student Engagement," Computers \& Education58(1) (2012): 162-171

${ }^{2}$ Urmee Khan, "Facebook Students Underachieve in Exams," Daily Telegraph (2009), https://www.telegraph.co.uk/education/educationnews/5145243/Facebook-students-underachieve-inexams.html, (Accessed on 25.09.2018)

${ }^{3}$ Rouis, et al. "Impact of Facebook Usage on Students' Academic Achievement: Role of self-regulation and trust,"Electronic Journal of Research in Educational Psychology Volume 9(3) (2011): 961-994, https://psycnet.apa.org/record/2011-30369-001, (Accessed on 27.09.2018)
} 
questionnaire methods and they have interviewed all the participants and all were MBBS. $^{4}$

Shanayyara Mahmood and Umer Farooq in 2014 researched on "Facebook addiction: A study of big- five factors and academic performance amongst students of IUB". Their research resulted that people who spends time on Facebook are very good from the educational perspective and its usage is very popular among the people.

Komal Singh Rambaree and Igor Knez in 2017, researched on the topic "Young people's identity and Facebook behavior: The role of gender and ethnicity". The findings of the study were that as in the digital era now, there is no face to face interaction existed and people are shifted towards the virtual world. ${ }^{6}$

Mereerat Manwong in 2015 researched on "Facebook addiction and its relationship with mental health among Thai High School Student". A cross-sectional method was used among high school students from four provinces of Thailand. In her study, it was found that children of high schools are associated with abnormal mental health issues. ${ }^{7}$

Tracii Ryan, et al. published a research article in a periodical publication of Journal of Behavioral Addictions, on $26^{\text {th }}$ August, 2014. They research on the topic "The Uses and Abuses of Facebook. In this research study, the researchers used the method of searching three large academic databases revealed 24 studies examining the uses and gratifications of Facebook. ${ }^{8}$

Shivani Vashishtha et al. published a research article about "Impact of Facebook Addiction Disorder (FAD) on Study Habits and Academic Achievement of Adolescents", in (MIER) Journal of Educational Studies, this research study highlighted that people of every age group are using different social networking sites these day. ${ }^{9}$

\footnotetext{
${ }^{4}$ Hassan Farooqi, et.al., "Effect of Facebook on the life of Medical University students," International archives of medicine 6(1) (2013): 40, https://www.ncbi.nlm.nih.gov/pmc/articles/PMC3853204/, (Accessed on 24.09.2018)

${ }^{5}$ Shanayyara Mahmood \& Umer Farooq, "Facebook Addiction: A Study of Big-Five Factors and Academic Performance Amongst Students of IUB," Global Journal of Management and Business Research: E Marketing Volume 14(5)(2014): 2249-4588, https://globaljournals.org/GJMBR_Volume14/6-Facebook-Addiction-AStudy-of-Big.pdf, (Accessed on 26.09.2018)

${ }^{6}$ Komal Singh Rambaree and Igor Knez,"Young People's Identity \& Facebook Behaviour: The Role of Gender and Ethnicity," Cogent Social Sciences Vol. 3(1) (2017): 1359895,

https://www.cogentoa.com/article/10.1080/23311886.2017.1359895, (Accessed on 28.09.2018)

${ }^{7}$ Nitt Hanprathet MSC, Mereerat Manwong MPH, Jiraporn Khumsri MSC, RungmaneeYingyeun MSC,

Muthita Phanasathit MD, FPC Psych T, "Facebook Addiction and its Relationship with Mental Health Among Thai High School Students," Journal of the Medical Association of Thailand= Chotmaihetthangphaet 98(3) (2015): S81-S90,

https://www.researchgate.net/publication/280023786_Facebook_Addiction_and_Its_Relationship_with_Mental Health_among_Thai_High_School_Students, Date of checking out the link: $28^{\overline{\mathrm{th}}}$ September, 2018.

${ }^{\overline{8}}$ Tracii Ryan, Andrea Chester, John Reece and Sophia Xenos, "The Uses and Abuses of Facebook: A Review on Facebook Addiction”, Journal of Behavioral Addictions Volume 3(3) (August 2014): 133-148, https://www.ncbi.nlm.nih.gov/pmc/articles/PMC4189307/, (Accessed on 24.10.2018)

${ }^{9}$ Shivani Vashishtha, et al. "Impact of Facebook Addiction Disorder (FAD) on Study Habits and Academic

Achievement of Adolescents," MIER Journal of Educational Studies, Trends \& Practices, Vol. 7(2) (November
} 
Julia M. Hormes, Brianna Kearns and C. AlixTimko published a research article about the topic "Craving Facebook? Behavioral Addiction to Online Social Networking and its Association with Emotion Regulation Deficits", on $29^{\text {th }}$ August 2014. The conclusion of the research study tells us the use of online social networking sites is potentially addictive. $^{10}$

OfirTurel, Qinghua He, GuiXue, Lin Xiao, Antoine Bechara published a research article on the topic "Examination of Neural Systems Sub-Serving Facebook 'Addiction' "in, 2014. This research study is about the addictive behaviors typically resulted from violated homeostasis of the impulsive inhibitory brain systems. ${ }^{11}$

Cecilie Schou Andreassen, et al. did research on the topic "Development of a Facebook Addiction Scale", on April 1 $1^{\text {st }}, 2012$. They created a Facebook Addiction Scale with the help of Bergen Facebook Addiction Scale and several other standardized self-report scales. High scores on the new scale were associated with delayed bedtimes and rising times $^{12}$

Soraya Mehdizadeh researched on the topic "Self-Presentation 2.0: Narcissism and SelfEsteem on Facebook" in 2010. The sample were collected from 100 Facebook users at York University and the research explained the facts about how people represent their personalities and identities on the specific social networking platform Facebook and what strategies they apply to promote their Facebook pages which are usually based on selfpromotional content. ${ }^{13}$

Mustafa Koc, and Seval Gulyagci researched on the topic "Facebook Addiction among Turkish College Students: The Role of Psychological Health, Demographic, and Usage Characteristics in 2013. The results revealed that weekly time commitment, social motives, severe depression, anxiety and insomnia positively predicted Facebook addiction. $^{14}$

2017): $195-207$.

https://www.researchgate.net/publication/322329881_Impact_of_Facebook_Addiction_Disorder_Fad_on_Stud

y_Habits_and_Academic_Achievement_of_Adolescents, (Accessed on 24.10.2018)

${ }^{10}$ Julia M. Hormes, et al. "Craving Facebook? Behavioral Addiction to Online Social Networking and its Association with Emotion Regulation Deficits," Society for the Study of Addiction Volume 109(12) (August 2014): 2079-2088, https://onlinelibrary.wiley.com/doi/abs/10.1111/add.12713, (Accessed on 24.10.2018)

${ }^{11}$ OfirTurel, Qinghua He, GuiXue, Lin Xiao and Antoine Bechara, "Examination of Neural Systems SubServing Facebook 'Addiction', SAGE Journals Psychological Reports Volume 115(3)(December 2014): 675695, http://journals.sagepub.com/doi/abs/10.2466/18.PR0.115c31z8, (Accessed on 24.10.2018)

${ }^{12}$ Cecilie Schou Andreassen, Torbjørn Torsheim, Geir Scott Brunborg and Ståle Pallesen, "Development of a Facebook Addiction Scale,” SAGE Journals Psychological Reports Volume 110(2) (April 2012): 501-517, http://journals.sagepub.com/doi/10.2466/02.09.18.PR0.110.2.501-517, (Accessed on 24.10.2018)

${ }^{13}$ SorayaMehdizadeh, "Self-Presentation 2.0: Narcissism and Self-Esteem on Facebook," Mary Ann Liebert, Inc., Cyberpsychology, Behavior, and Social Networking Vol. 13(4) (August 2010), https://www.liebertpub.com/doi/abs/10.1089/cyber.2009.0257, (Accessed on 24.10.2018)

${ }^{14}$ Mustafa Koc, and SevalGulyagci, "Facebook Addiction among Turkish College Students: The Role of Psychological Health, Demographic, and Usage Characteristics," Cyberpsychology, Behavior, and Social Networking Vol.16(4) (Mary Ann Liebert, Inc., April 2013),

https://www.liebertpub.com/doi/abs/10.1089/cyber.2012.0249, (Accessed on 24.10.2018) 


\section{Research Methodology}

Researcher applied mix methodology in his study which includes the qualitative questionnaire method by taking interviews of parents and teachers and the quantitative cross sectional method in which survey forms are filled by the students, in order to investigate "The Impact of Excessive use of Facebook on Youth of Pakistan". It is a combination research as both methods are applied in it. In the quantitative part of the study, the target population is the youth of Karachi and the sample of the study are the students of different universities and colleges, aged from 18 to 30 . The sample size is 50 in which half of the population includes boys and half girls and in the qualitative part of the research study, the interviews are conducted from a sample size of 10 including parents and teachers of Facebook users. The universe of the research study is Karachi, the city of Pakistan and the research has done to check out the impacts of excessive use of Facebook on the youth of Karachi. The researcher has used the thematic pattern to explain the point of views of the interviewees.

To dig out the answers of the research questions, the researcher has taken an appointment for an interview from the respondents first. The participants are parents and teachers of the youth of Karachi. As the respondents allowed the researcher to record the interviews, but demanded to not disclose their names. So, the researcher used codes for the respondents such as "PA" for parents and "TE" for teachers.

\section{Data Collection}

The researcher has gathered the data by taking 10 face to face interviews from the respondents by taking qualitative questionnaires to them and 50 survey forms filled up by different college and university students. The data gathered has transcribed in the same way as the interviewees shared their experiences with the researcher about the impacts of Facebook on their lives and the results of data collection in the manner of survey forms are being expressed in the form of charts below.

\section{Social Media Website}

PA1 stated that my children mostly use Facebook as it is the popular social networking site

PA2 told that children these days are involved in as compared to other social networking sites.

PA3 said that my children continuously use Facebook, as this social media website makes an individual antisocial.

PA4 said that my son use Facebook and it keeps him away from his studies. Due to this he cannot pay proper attention to his studies.

PA5 told that these days, children mostly use Facebook as it has contained some different features. 


\section{Is Facebook Important in Children's Life?}

PA1 said that if children are studying then Facebook should not be vital for them. A child's education can be disturbed due to its extreme addiction.

PA2 said that Facebook is not necessary for the kids and I think being a parent, we should not give internet access to the kids, unless they are mature enough to judge themselves and the positive and negative aspects of their lives.

PA3 said Facebook is not a life for a child. They can live without it, even the cellphones should be limited for the kids.

PA4 told that Facebook is not significant, especially for those who are students as it highly impacts on the children grades.

PA5 said that youngsters do not eat lunch as they absorbed themselves into mobile and it is not a need of children, although it plays a negative role in their lives.

\section{Facebook Sucks the Study Time of Children}

PA1said that several times, I observed my kids using Facebook and forget that on the next day, there's a class test waiting for them.

PA2 stated that children waste their precious hours on Facebook, as they do not show their proper concentration on their studies.

PA3 said that I have noticed that more than one-time, children just look at their cellphones to check out is there any new message came for them, even their fingers are continuously stick to the keypad of mobile phones.

PA4 said that all the time children are busy in using Facebook.

PA5 said that every time they are using Facebook nonstop, as it has become a necessary part and parcel of their daily life.

\section{Facebook Spoils Family Time}

PA1 said that due to Facebook, our family time gets disturb. When they have mobile phones in their hands all the time, they just forget the real world and involved in virtual world.

PA2 said that I have detected that my kids evaded the family conversation and keep busy in mobile phones.

PA3 told that kids are kept using mobile phones, even when we sit for dinner their attention is on their messages and online chats rather than on food. 
PA4 told that it happened most of the time that the food is in front of the kids, but they avoid the meal over Facebook, as after a hard work we earn food for them and they should give value to it.

PA5 stated that this Facebook has created a distance among the people and there is no doubt that our family time gets disturb always.

\section{Children Deny to Task given by Parents}

PA1 said that it really happened whenever I give any task to my kids they just got engaged with the screens of mobile phones and of course constantly using Facebook on it.

PA2 expressed that children usually abandonment to their parents, while they are doing chatting with their friends on Facebook.

PA3 shared that whenever I give work to my kids, they just ignoreit and even don't give reply to my questions.

PA4 said that an individual engages in Facebook up to a high level that he neglects every chore, as if I want to go to the doctor with my son, he does not take me to the clinic, even his priorities got changed.

PA5 expressed his views that these days, children avoid all house duties, as whenever I asked someone to bring bread fromthe market, they simply say no without taking a second.

\section{Social Media Website}

TE1told that Facebook is her favorite social media platform and she thinks that for the students of present time, Facebook has become a drug without which they cannot survive a single day.

TE2 expressed his views about Facebook that this social media platform has become very popular,especially among the adolescents and the people of every age are also taking keen interest in Facebook.

TE3 expressed her views that she's very fond of using Facebook and according to her, this social media website is very much favorite of almost all the students of colleges and universities.

TE4 told that in all the social media websites, she uses Facebook the most and nowadays, all the people are using it much addictively.

TE5 said that she uses two social media platforms the most that are Facebook and WhatsApp. According to her, the students of schools, colleges and universities use Facebook very addictively in their routine life. 


\section{Is Facebook Important for Your Life and Students' Life?}

TE1 said that Facebook is important for everyone nowadays, because it helps in connecting us to the world and according to her; it works as a bridge of interaction. But, on the other side, adolescents are misusing it by posting thousands of things like whenever they eat a meal or visit any place they click a picture of it and post it on Facebook.

TE2 said that it helps me, my students and my fellows in communicating with each other, as if they want to contact me for education purpose or for any other important work and they don't have my contact number, so they can directly search my account on Facebook by writing my name in the search bar and can contact me without facing any difficulty.

TE3 told that Facebook is a great way with which communication with the world is just at a distance of our fingertips due to the use of cell phones.

TE4 told that this social media platform is very significant as it keeps us connected with our fellows and with the world.

TE5 said that Facebook is not beneficial at all, especially for the young generation. It's just wastage of time because there's nothing informative or knowledgeable content available at this platform.

\section{How Many Times Do You Use Facebook every day?}

TE1 said that she uses Facebook once in a day to check out the posts of her family members, her friends and her students, she also posts her pictures and status about her life happenings and sometimes she likes to watch entertaining and informative videos on this site. According to her, the young people are using it more than needed; especially the teenagers are sacrificing their whole nights just for the sake of using Facebook.

TE2 said that he uses Facebook once or twice a day to keep him updated about the latest happenings and to check out the messages and posts of his fellows and he thinks that the young ones are using this site all the time because of the trending of posting each and every moment they live.

TE3 told that she uses Facebook many times in a day. Whenever she gets time after her classes, she's used to check the latest updates on Facebook during travelling somewhere and when she's at home and gets free time after completing all her domestic works, she uses Facebook and she thinks that her students and other young people also use this site many times in a day.

TE4 expressed that she uses Facebook many times in a day, as it helps her connected with her students and other fellow people and her students also use this social media website very actively to share their talent and personal skills on their timelines.

TE5 told that she uses Facebook once in a day or once in two days. She uses it in a limited way and she just checks out whether there's any informative or news worthy 
video uploaded by people or by any page. She thinks that students use this site almost whole day.

\section{Facebook spoils Class Time}

TE1 said that whether, students use Facebook or any other social media website, but yes, it happens that they are used to scroll their cell phone screens all the time.

TE2 said that during class time, I don't allow my students to use their cell phones because it can destroy my tempo during taking class.

TE3 told that nowadays, students are very sharp minded and whether, I don't want them or allow them to use cell phones in class timing, some students still use it by hiding cell phones under the desk and they have become really expert.

TE4 said that yes, sometimes it happens that some students use cell phones during attending lectures which spoils the class time, as everyone's attention gets divert due to this.

TE5 told that no, I strictly don't allow students to use their cell phones a bit during class timing because according to me, this is quite unethical and this can divert everybody's focus from learning during my lectures.

\section{Do the Students Give Instant Answers to the Teachers?}

TE1 said that students often don't give instant replies whenever I asked any question, as their focus is not properly on what I teach them. When the students don't use Facebook, their focus is still not on their studies.

TE2 told that yes, students give answers to my questions on time because I deal with them strictly during class timing.

TE3 told that students focus has diverted due to this much addictive use of Facebook and when teachers or their parents give them any task to do or ask them any question, they give their first priority to answer their friends and fellows on Facebook instead of answering their parents or teachers and sometimes, these things happen in my class timing as well which make me feel really bad and disrespectful.

TE4 said that students give reply to my questions actively in class, as I try to teach them in a humorous way, so that they can also take part in class discussions and activities.

TE5 said that students give answer to my questions instantly and don't deny to the tasks I give them because I deal in the matter of studies in a strict and straight way. 
Data Analysis

Figure-1

Status of Having Facebook Account

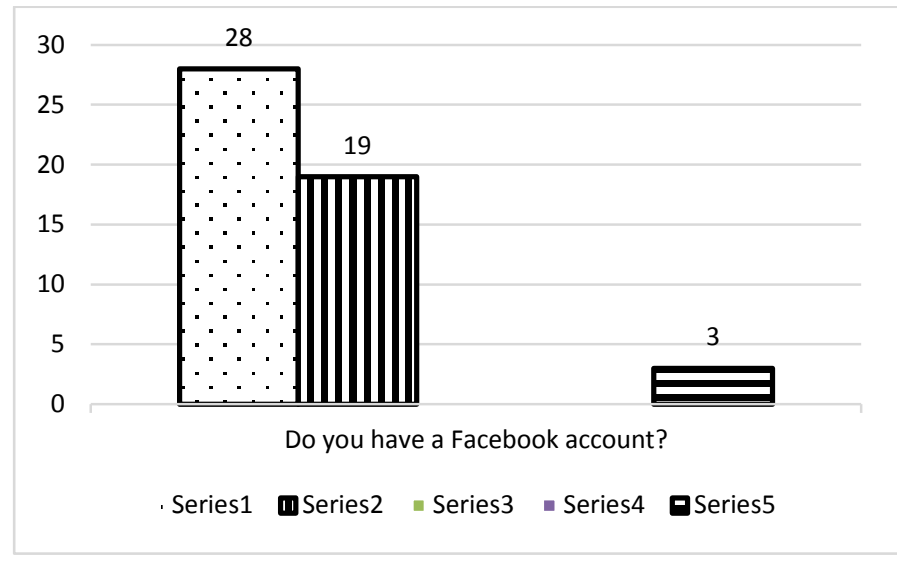

Developed by authors

Figure-2

If the Facebook Account is a Favorite Social Network Site

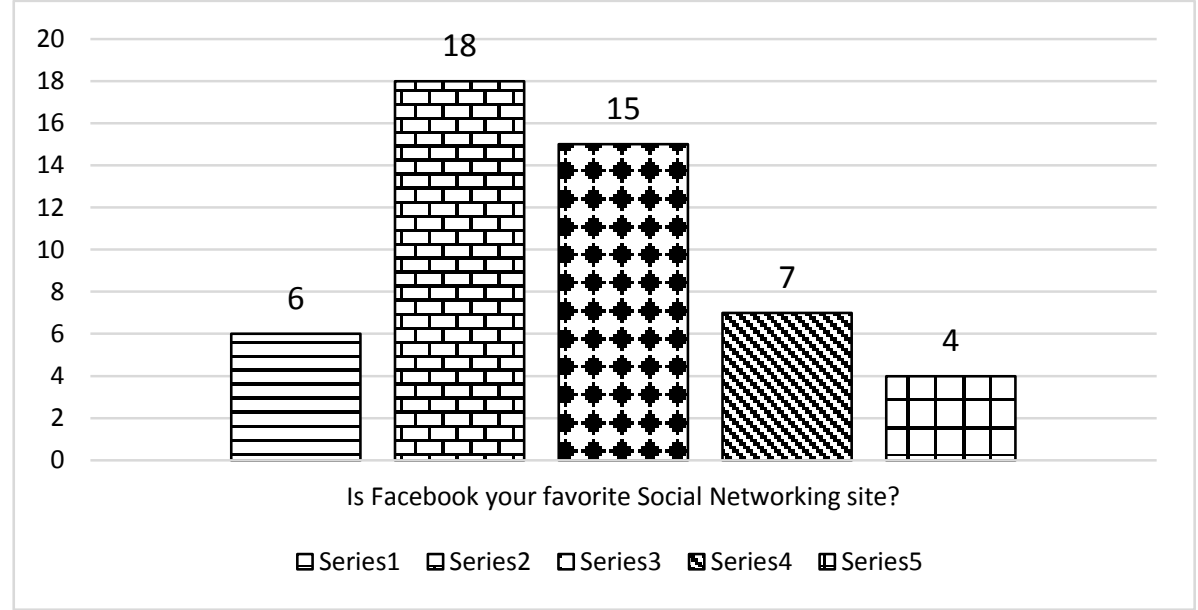

Developed by authors 
Figure-3

Status of Usage of Facebook Account on Daily Basis

DO YOU USE FACEBOOK EVERY DAY?

图1 $\mathbf{\Delta}$ 田

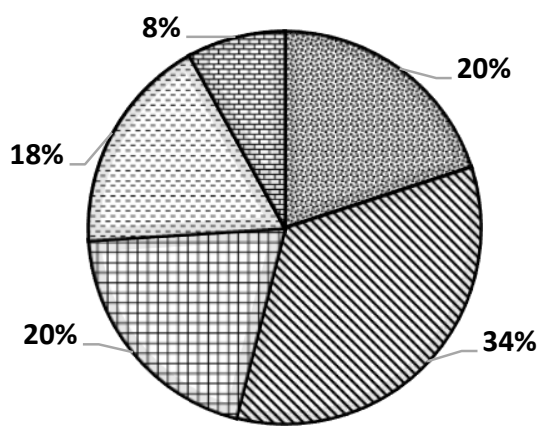

Developed by authors

Figure-4

Status of Addiction of Facebook Account Usage

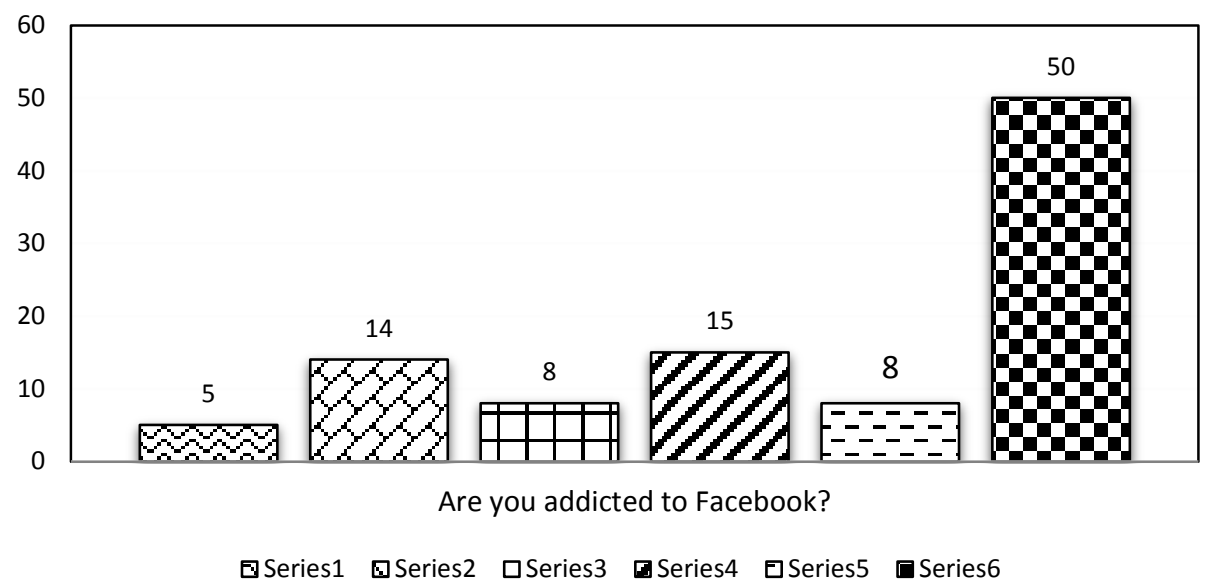

Developed by authors 
Figure-5

User's Photo on Facebook Account

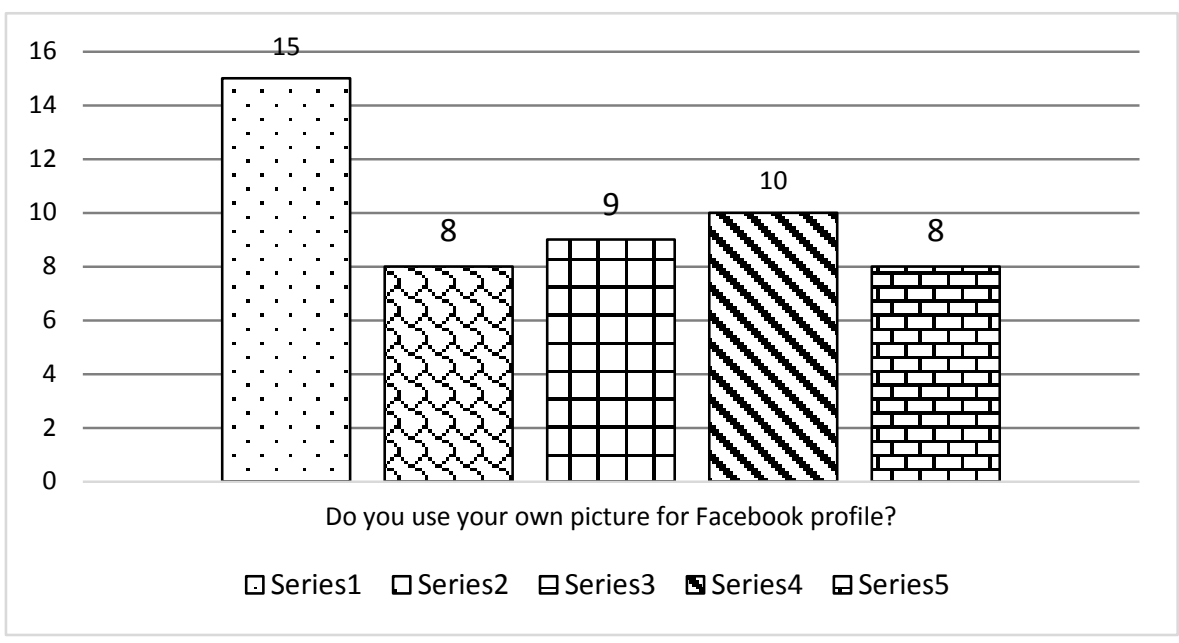

Developed by authors

Figure-6

Facebook Account a Convenient Source of Communication

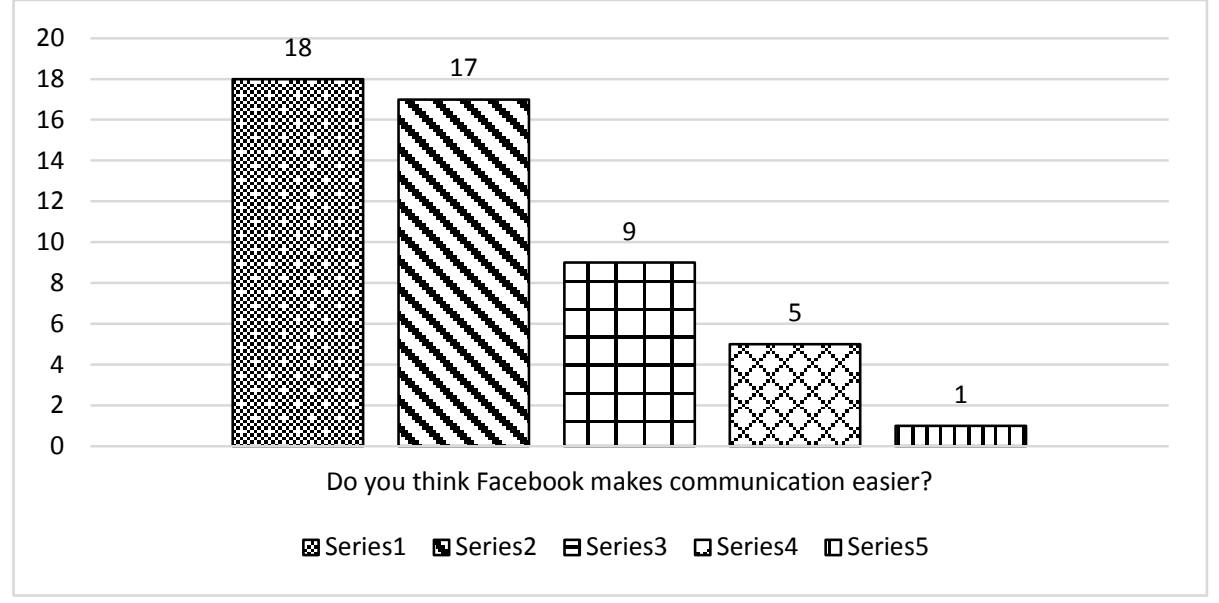

Developed by authors 
Figure-7

Facebook Account, A Time Consuming Activity

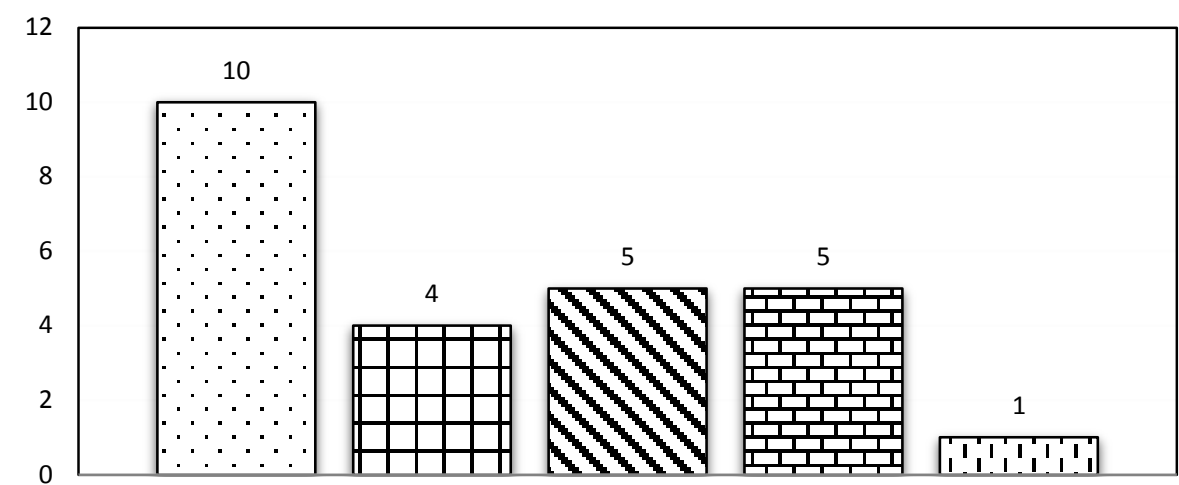

Do you think that Facebook sucks up your family time/ study time?

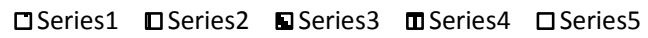

Developed by authors

Figure-8

Impact of Facebook Account on User's Speaking / Actions

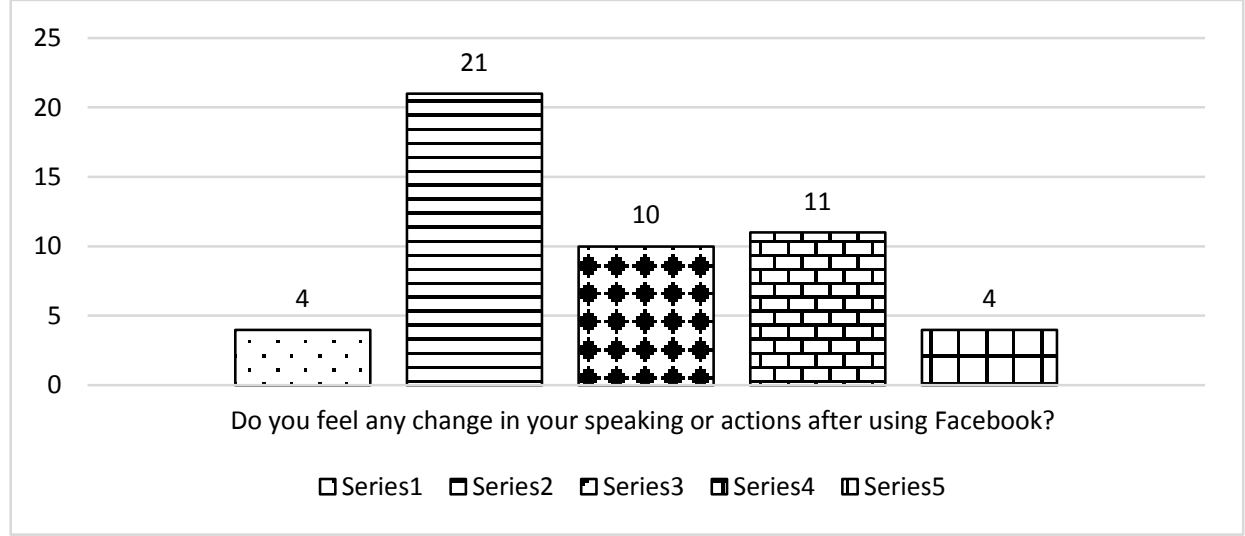

Developed by authors 
Figure-9

Facebook Account's Effects on Users' Performance

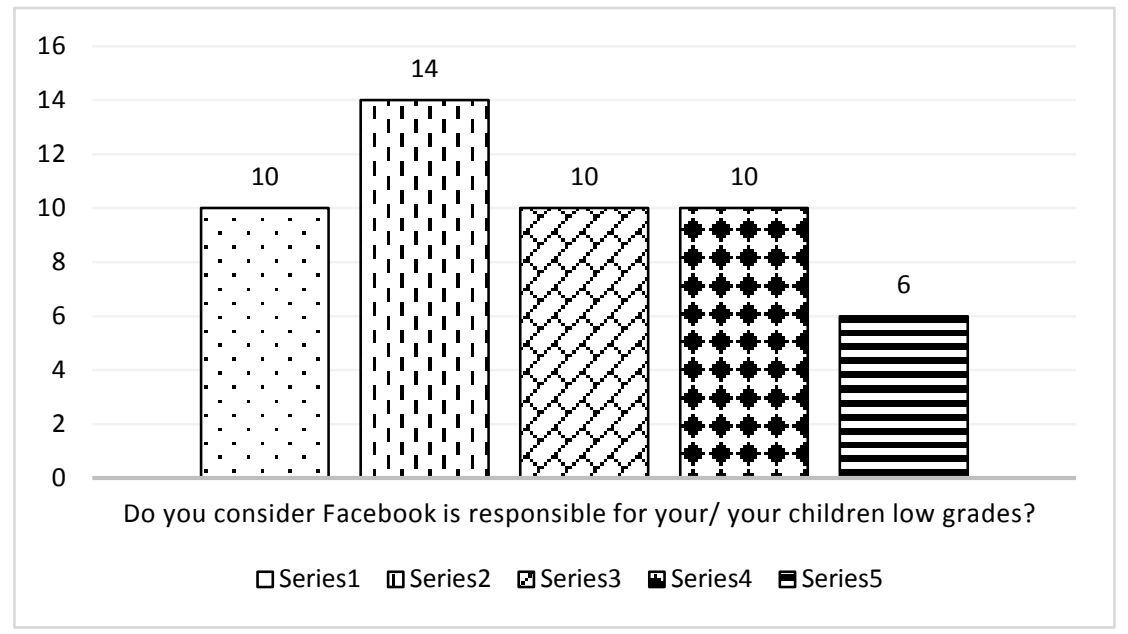

Developed by authors

Figure-10

Experience of Cyber Maltreatment at Facebook Account

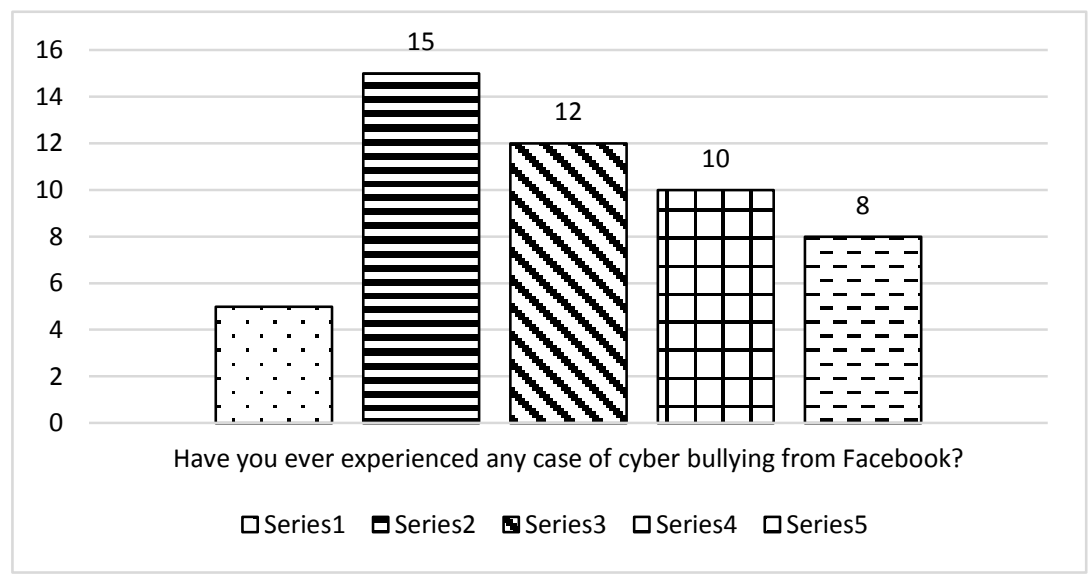

Developed by authors 
Figure-11

Impact of Facebook Account on User's Health

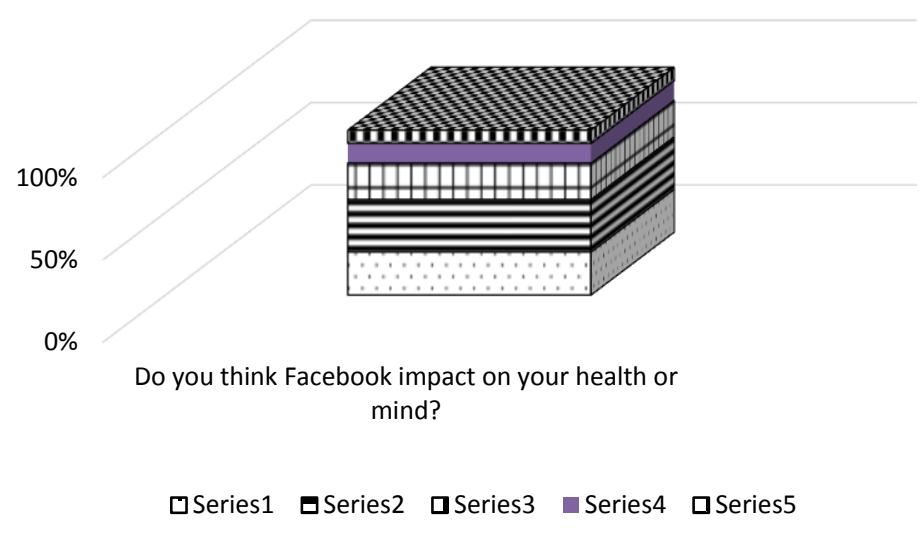

Developed by authors

Figure-12

Hacking of Facebook Account

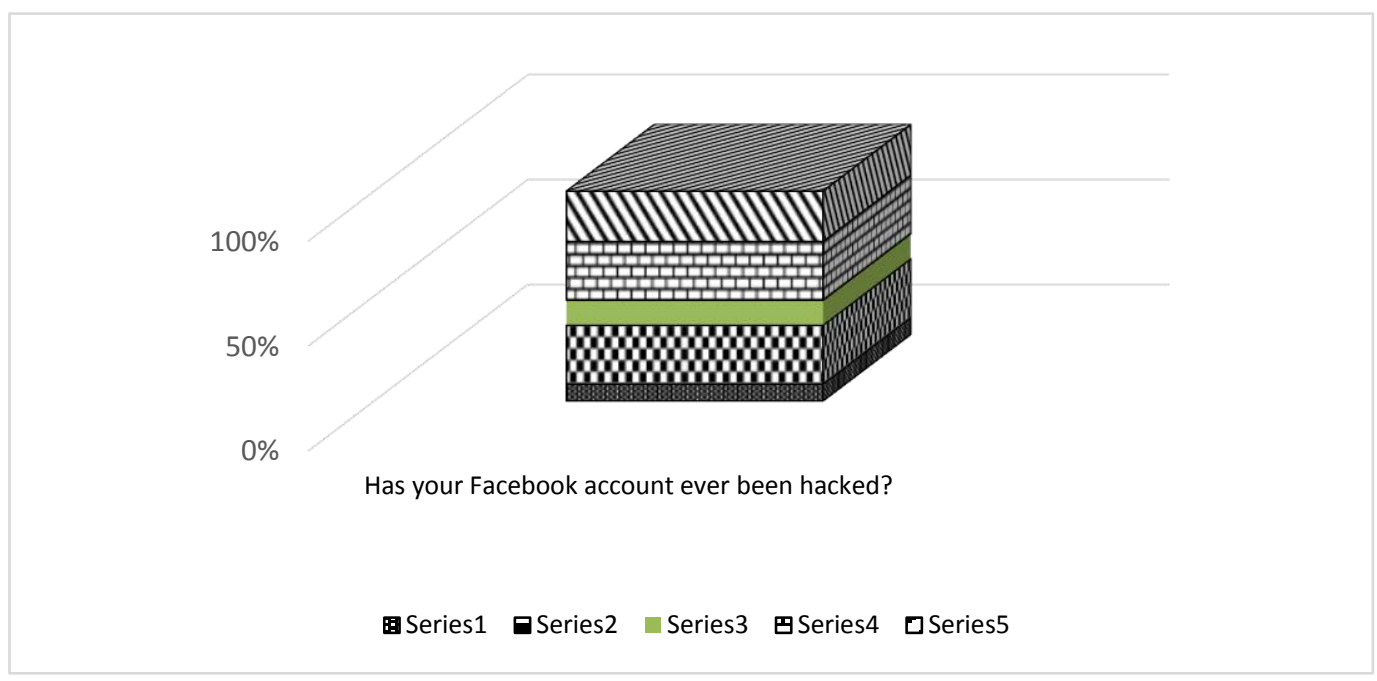

Developed by authors 


\section{Figure-13}

Experiencing a Threat Due to Facebook Account

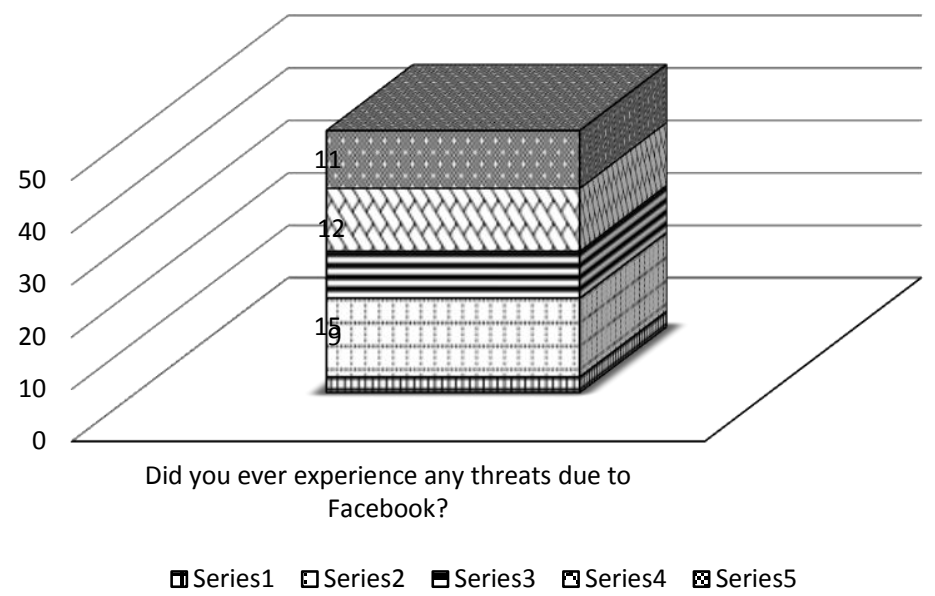

Developed by authors

Figure-14

Status of Receiving any Harassment on Facebook Account

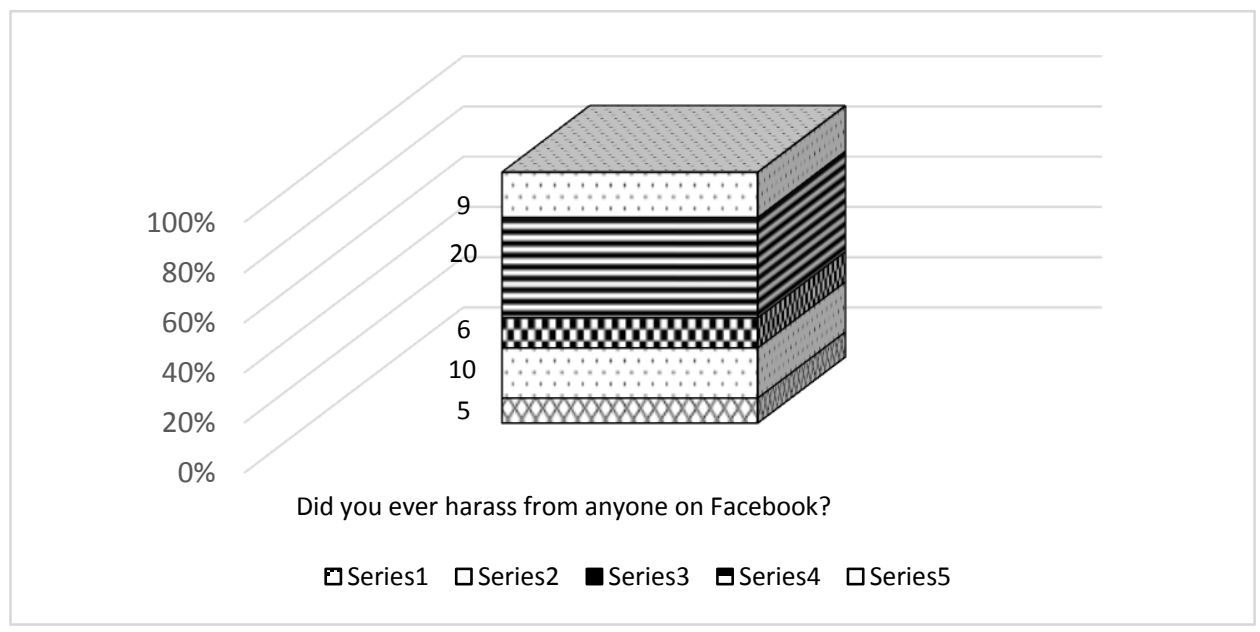

Developed by authors 
Figure-15

Impact of Facebook Account on Your Social Activity

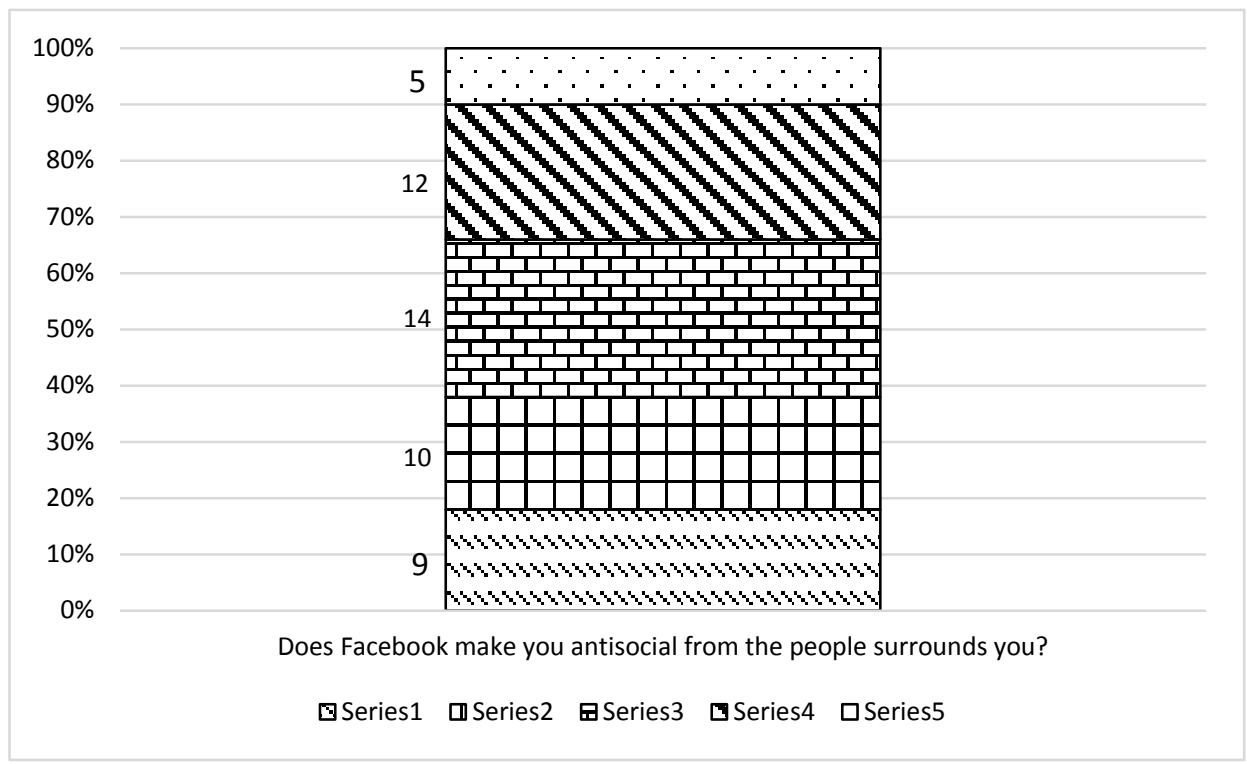

Developed by authors

The first bar chart is about the amount of people who have Facebook accounts and the chart shows that there's a total of 50\% in which 3\% of the people don't have Facebook accounts, $19 \%$ of them agree to have it and $28 \%$ strongly agree to have a Facebook account. The second bar chart is about "Is Facebook your favorite social networking site?" and the chart tells us that in a total of $50 \%$; $6 \%$ strongly agree, $18 \%$ agree, $15 \%$ neutral, $7 \%$ disagree and $4 \%$ of them strongly disagree with the statement.

The third is the pie chart with a total percentage of 100 and it is about "Do you use Facebook every day?" and the replies from people tells us that $20 \%$ of them strongly agree, $34 \%$ agree, $20 \%$ neutral, $18 \%$ disagree and $8 \%$ strongly disagree with the statement that they use Facebook every day.The fourth is the bar chart with a total number of 100 and it's about "The Addiction of Facebook". This chart shows that 5\% people strongly agree, $14 \%$ people agree, $8 \%$ people are neutral, $15 \%$ people disagree and $8 \%$ people strongly disagree with the statement. While, the rest $50 \%$ people didn't reply to the question. The fifth one is again a bar chart which is about "The people who use their own pictures as their profile photo". The chart shows a total average of $50 \%$ in which $15 \%$ of people strongly agree, $8 \%$ people agree, $9 \%$ people are neutral, $10 \%$ people disagree and $8 \%$ people strongly disagree with the statement. The sixth bar chart is about "Facebook makes communication easier"; with an average of $50 \%$ in which $18 \%$ 
strongly agree, $17 \%$ agree, $9 \%$ neutral, $5 \%$ disagree and $1 \%$ strongly disagree with the statement. The seventh bar chart is about "Facebook sucks up family time and class time". It shows an average of $25 \%$ in which $10 \%$ of people strongly agree, $4 \%$ agree, $5 \%$ neutral, $5 \%$ disagree and $1 \%$ strongly disagree with the statement. The eighth bar chart is about "The change in speaking or actions after using Facebook". It describes an average percentage of 50 in which $4 \%$ strongly agree, $21 \%$ agree, $10 \%$ neutral, $11 \%$ disagree and $4 \%$ strongly disagree with the statement. The ninth bar chart is about "The impact of Facebook on children's low grades". It shows a total amount of $50 \%$ in which $10 \%$ people goes with strongly agree, $14 \%$ with agree, $10 \%$ with neutral, $10 \%$ with disagree and $6 \%$ with strongly disagree for considering Facebook responsible for low grades of children.

The tenth bar chart is about "The experience of facing any cyber bullying from Facebook". This chart describes in a total of 50\%, 5\% strongly agree, $15 \%$ agree, $12 \%$ neutral, $10 \%$ disagree and $8 \%$ strongly disagree with the statement of facing any cyber bullying issue from this site. The eleventh is the cube chart which is about "The impact of Facebook on health and mind". This chart describes an average amount of $100 \%$ in which $26 \%$ strongly agree, $34 \%$ agree, $22 \%$ neutral, $10 \%$ disagree and $8 \%$ strongly disagree to the statement that Facebook affects health and minds of adolescents.

The twelfth cube chart is about "The experience of facing the issue of Facebook account hacks". The chart explains that in a total of $100 \% ; 8 \%$ strongly agree, $34 \%$ agree, $10 \%$ neutral, $26 \%$ disagree and $22 \%$ strongly disagree to the problem of facing hack issues of their Facebook accounts.

The thirteenth cube chart is about "The threats experienced due to Facebook". It explains that in a total of $50 \% ; 3 \%$ strongly agree, $17 \%$ agree, $9 \%$ neutral, $11 \%$ disagree and $10 \%$ strongly disagree with the issue of facing any threats through Facebook. The fourteenth cube chart is about "The cases of harassment on Facebook". The chart describes that in a total of 50\%; 5\% strongly agree, $10 \%$ agree, $6 \%$ neutral, $20 \%$ disagree and $9 \%$ strongly disagree with the issue of facing any harassment cases due to Facebook. The fifteenth is the bar chart which is about "Facebook makes an individual antisocial". This chart has an average total of $100 \%$ in which 18\% strongly agree, $20 \%$ agree, $28 \%$ neutral, $24 \%$ disagree and $10 \%$ strongly disagree with the statement.

\section{Findings and Discussions}

To know the Facebook impacts and its symptoms on the youth is not an easy task at all. The researcher studied and researched on the previous studies done by various researchers across the world and found out that there's a huge impact of Facebook usage and a number of effects on lives of people due to its much addictive consumption. The researcher collected data from students of different universities and colleges by filling out the survey forms and analyzed the data in the form of bar charts, pie charts and cube charts. The data analysis explains that in an estimated population of about 100\%; $90 \%$ of the population uses this specific social networking site which is Facebook and in that $90 \%$ of the adolescents, more than a half of them consider this website as their favorite one. A lot of people admitted to use this social platform every day and many use it very 
rarely and some amount of people don't use it as a drug as they consider it not a much needed thing. Many use their own pictures for their profile and many don't. 35\% people in a total of 50\% consider that Facebook makes communication easy and a good source of interaction, while a few of them think it's not that much useful. In a total of 50\%, around $24 \%$ thinks that it highly affects the academic progress of students and their grades and some of the rest replied neutrally and a few thinks it doesn't affect in anyway. $20 \%$ in a 50\% population got targeted for cyber bullying by other people on Facebook and $42 \%$ in $100 \%$ experienced the hacking issue by anonymous on Facebook. 20\% in a total of 50\% are victims of facing threats on Facebook and a number of people have become victims of harassment cases due to Facebook. $60 \%$ of the $100 \%$ population accepts the fact that Facebook is responsible for the negative impacts on the health and mental disorders of youngsters and around 38\% thinks that the limitless consumption of Facebook makes an individual antisocial.

However, the interviews conducted from teachers and parents explain the impacts of Facebook in a much detailed way. According to the parents of Facebook users and activists, the children of this generation are living in a virtual world instead of living in real world. According to many guardians, the use of social media is increasing because such hand-handling devices have introduced the smartest device in all devices which is mobile phone due to which, the doors to reach the virtual world can open for the youth at anytime and anywhere. The continuous usage of cell phones and the social media websites, specifically Facebook, is the main reason behind their spoiled habits. The youngsters have changed their priorities and give first priority to the comment on posts of their friends, checking out new notifications, poking people, posting pictures, videos and the life events that sometimes children of the present time have become much lazy, as they don't visit their relatives, friends and fellows at their homes when they have Facebook in their smart phones, they can start chat at own homes just by sending messages to them on Facebook. According to teachers, children don't give importance to their studies as they were used to give in the past time, before the emergence of social media websites like Facebook.

This is a virtual place which gives the young ones a huge variety of options to make them entertain their selves by doing so many things like some of the adolescents are taking keen interest in watching funny or informative videos, some wants to share their pictures of living in different moments with their friends, some likes to involve in deep conversations to their fellows and group chatting and some wants to comment on others post and even give reactions to them. Sometime, according to some teachers, this website doesn't provide informative and knowledgeable content which can help students in their academic process or projects of universities or colleges. Many of them consider it as useless, as it easily wastes the precious time of the students in which they can study or do other work.

Teachers also explained that because of this much consumption of using Facebook, students focus has diverted from their studies and they are not even able to focus on the lectures during class timing. It has become a worst habit of continuously scrolling cell phones just to check out whether any new notifications or messages are waiting for them and this much usage has make them too much addicted to Facebook that even many don't 
sleep at night and sacrifice their sleeping time for it. People also face mental disorders like anxiety, insomnia and deep depression due to which their complete life cycle can destroy.

Where there are lots of negative impacts, on the other hand, there are positive aspects of using Facebook as well. One of the main affirmative points is that Facebook creates a bridge between an individual and the world. It helps in making strong bonding between the ones who live far from each other, as if any of the relative or friend is living in any foreign country and the other one cannot afford to visit them, they can directly meet them by doing live video calls with no charges applied. This is the main positive aspect of Facebook which connects people to their loved ones. The researcher found that Facebook is a complete package of information, communication and entertainment which can be considered as one of the most significant factors due to which youth are more involved into this particular website than any other. Somehow, it can be justified as the excessive usage of Facebook depends on the people that how more or less they consume it and in how many ways the level of consumption is damaging their own selves because it's not about Facebook which is using people, but it's about people who're using Facebook.

\section{Result}

Although Facebook has a huge affirmative side today, some would say that its negative repercussions could highly overweight its benefits. However, the researcher believes that the repercussions of Facebook would only happen in cases when an individual is Facebook addicted and using it in an excessive amount. The researcher further suggests that Facebook is beneficial as if people learn to use it in manageable levels and if they keep a balance between the usage of Facebook and their physical life, this social media platform could become a great avenue for better physical, mental, emotional, interpersonal; and even spiritual development.

\section{Bibliography}

Liana Evans, Social Media Marketing(Pearson Education Inc. as Que Publishing, 2010), 26 and 27.

Morgan Thornton, ZamzamKalibala, Edward Ewemie, HakanAlim and Wilmington University, "Face as an Organization". https://scholar.google.com.pk/scholar?hl=en\&as_sdt=0\%2C5\&q=facebook+as+an+organ ization+by+Morgan+Thornton\%2C+ZamzamKalibala\%2C+Edward+Ewemie $\% 2 \mathrm{C}+$ Haka nAlim+and+Wilmington+University $\% 2 \mathrm{C}+\& \mathrm{btnG}=\left(\right.$ Accessed on $1^{\text {st }}$ October, 2018) .

SadiaMaqsood, "Social Media and You," Dawn.com (October 2017)

https://www.google.com/amp/s/www.dawn.com/news/amp/1366642 (Accessed on $26^{\text {th }}$

September, 2018). 
VivekWadhwa, "How social media changed the world," Newsday.com (February 2014) https://www.newsday.com/opinion/oped/how-social-media-changed-the-world-vivekwadhwa-1.6962077 (Accessed on $27^{\text {th }}$ September, 2018).

News Desk, "Facebook and Twitter beneficial for kids, young people: study," Tribune.com.pk (June 2017), https://www.google.com/amp/s/tribune.com.pk/story/1447005/using-facebook-twitterbeneficial-kids-young-people-study $/ \% 3$ famp $=1$, (Accessed on $26^{\text {th }}$ September, 2018).

Kristin Trapp, "Effects of Facebook on Teenagers: Positive and Negative,"Wehavekids.com (June 2016), https://wehavekids.com/parenting/Teens-andFacebook, (Accessed on $26^{\text {th }}$ September, 2018), https://academic.oup.com/jcmc/article/12/4/1143/4582961, (Accessed on $25^{\text {th }}$ September, 2018).

Hassan Farooqi, Hamza Patel, Hafiz Muhammad Aslam, IqraQamar Ansari, Mariya Khan, NoureenIqbal, HiraRasheed, QamarJabbar, SaqibRaza Khan, Barira Khalid, AnumNadeem, RaunaqAfroz, Sara Shafiq, Arwa Mustafa and NaziaAsad, "Effect of Facebook on the life of Medical University students," International archives of medicine6(1) (2013): 40, https://www.ncbi.nlm.nih.gov/pmc/articles/PMC3853204/, (Accessed on $24^{\text {th }}$ September, 2018).

ReynolJunco,"The relationship between frequency of Facebook use, participation in Facebook activities, and student engagement," Computers \& Education58(1) (2012): 162-171, https://www.sciencedirect.com/science/article/pii/S0360131511001825, (Accessed on $24^{\text {th }}$ September, 2018).

UrmeeKhan,"Facebook students underachieve in exams," Daily Telegraph (2009), https://www.telegraph.co.uk/education/educationnews/5145243/Facebook-studentsunderachieve-in-exams.html, (Accessed on $25^{\text {th }}$ September, 2018).

ShanayyaraMahmood\&UmerFarooq, "Facebook Addiction: A study of big-five factors and academic performance amongst students of IUB," Global Journal of Management and Business Research: E Marketing Volume 14(5)(2014): 2249-4588, https://globaljournals.org/GJMBR_Volume14/6-Facebook-Addiction-A-Study-ofBig.pdf, (Accessed on $26^{\text {th }}$ September, 2018).

NittHanprathet MSC, MereeratManwong MPH, JirapornKhumsri MSC, RungmaneeYingyeun MSC, MuthitaPhanasathit MD, FPC Psych T, "Facebook addiction and its relationship with mental health among Thai high school students," Journal of the Medical Association of Thailand= Chotmaihetthangphaet 98(3) (2015): S81-S90, https://www.researchgate.net/publication/280023786_Facebook_Addiction_and_Its_Rela tionship_with_Mental_Health_among_Thai_High_School_Students, Date of checking out the link: $28^{\text {th }}$ September, 2018.https://jpma.org.pk/article-details/7283 (Accessed on $28^{\text {th }}$ September, 2018).

Komal Singh Rambaree and Igor Knez,"Young people's identity \& Facebook behaviour: The role of gender and ethnicity," Cogent Social Sciences Volume 3(1) (2017): 1359895, 
https://www.cogentoa.com/article/10.1080/23311886.2017.1359895, (Accessed on $28^{\text {th }}$ September, 2018).

Rouis, Sana, Limayem, Moez, Salehi-Sangari, Esmail, "Impact of Facebook Usage on Students' Academic Achievement: Role of self-regulation and trust,"Electronic Journal of Research in Educational Psychology Volume 9(3) (2011): 961-994, https://psycnet.apa.org/record/2011-30369-001, (Accessed on $27^{\text {th }}$ September, 2018).

http://pu.edu.pk/images/journal/szic/pdf_files/2_Ahsan\%20ul\%20Haq $\% 20 \% 26 \% 20$ Sohai 1\%20Chand_v34_no2_2012.pdf, (Accessed on $21^{\text {th }}$ September, 2018).

ShivaniVashishtha, SonaAhuja and Mani Sharma, "Impact of Facebook Addiction Disorder (FAD) on Study Habits and Academic Achievement of Adolescents," MIER Journal of Educational Studies, Trends \& Practices Volume 7(2) (November 2017):195 207,

https://www.researchgate.net/publication/322329881_IMPACT_OF_FACEBOOK_ADD ICTION_DISORDER_FAD_ON_STUDY_HABITS_AND_ACADEMIC_ACHIEVEM ENT_OF_ADOLESCENTS, (Accessed on $24^{\text {th }}$ October, 2018).

Tracii Ryan, Andrea Chester, John Reece and Sophia Xenos, "The uses and abuses of Facebook: A review on Facebook addiction,"Journal of Behavioral Addictions Volume 3(3) (August 2014): 133-148, https://www.ncbi.nlm.nih.gov/pmc/articles/PMC4189307/, (Accessed on $24^{\text {th }}$ October, 2018).

Julia M. Hormes, Brianna Kearns and C. AlixTimko, "Craving Facebook? Behavioral Addiction to Online Social Networking and its Association with Emotion Regulation Deficits," Society for the Study of Addiction Volume 109(12) (August 2014): 2079-2088, https://onlinelibrary.wiley.com/doi/abs/10.1111/add.12713, (Accessed on $24^{\text {th }}$ October, 2018).

OfirTurel, Qinghua He, GuiXue, Lin Xiao and Antoine Bechara, "Examination of Neural Systems Sub-Serving Facebook 'Addiction'," SAGE Journals Psychological Reports Volume 115(3)(December 2014): 675-695, http://journals.sagepub.com/doi/abs/10.2466/18.PR0.115c31z8, (Accessed on $24^{\text {th }}$ October, 2018).

CecilieSchou Andreassen, TorbjørnTorsheim, Geir Scott Brunborg and StålePallesen, "Development of a Facebook Addiction Scale," SAGE Journals Psychological Reports Volume 110(2) (April 2012): 501-517, http://journals.sagepub.com/doi/10.2466/02.09.18.PR0.110.2.501-517, (Accessed on $24^{\text {th }}$ October, 2018).

SorayaMehdizadeh, "Self-Presentation 2.0: Narcissism and Self-Esteem on Facebook," Mary Ann Liebert, Inc., Cyberpsychology, Behavior, and Social Networking Voume13(4) (August 2010), https://www.liebertpub.com/doi/abs/10.1089/cyber.2009.0257, (Accessed on $24^{\text {th }}$ October, 2018). 
Mustafa Koc, and Seval Gulyagci, "Facebook Addiction among Turkish College Students: The Role of Psychological Health, Demographic, and Usage Characteristics,"Mary Ann Liebert, Inc., Cyberpsychology, Behavior, and Social Networking Voume 16(4) (April 2013),

https://www.liebertpub.com/doi/abs/10.1089/cyber.2012.0249, (Accessed on $24^{\text {th }}$ October, 2018).

https://akademiai.com/doi/abs/10.1556/2006.4.2015.013, (Accessed on $24^{\text {th }}$ October, 2018).

https://www.sciencedirect.com/science/article/pii/S0747563210000646, (Accessed on $24^{\text {th }}$ October, 2018).

https://www.shconferences.org/articles/shsconf/abs/2014/02/shsconf_saci2013_00001/sh sconf_saci2013_00001.html, (Accessed on $24^{\text {th }}$ October, 2018).

https://www.sciencedirect.com/science/article/pii/S0360131515000160, (Accessed on $24^{\text {th }}$ October, 2018). 